\title{
Effect of Relative Humidities on Microstructural, Barrier and Mechanical Properties of Yam Starch-Monoglyceride Films
}

\author{
Fábio Avelino Bublitz Ferreira ${ }^{1}$, Maria Victória Eiras Grossmann ${ }^{1 *}$, Suzana Mali ${ }^{1}$, Fábio \\ Yamashita $^{1}$ and Lisandro Pavie Cardoso ${ }^{2}$ \\ ${ }^{I}$ Departamento de Tecnologia de Alimentos e Medicamentos; Centro de Ciências Agrárias; Universidade Estadual \\ de Londrina; C. P.: 6001; 86051-990; Londrina - PR - Brasil. ${ }^{2}$ Departamento de Física Aplicada; Universidade \\ Estadual de Campinas; C. P.: 6165;13083-970; Campinas - SP - Brasil
}

\begin{abstract}
The effect of monoglyceride on microstructural, barrier and mechanical properties of casted yam starch films were investigated in different relative humidities $(\mathrm{RH})$ and compared with glycerol-starch films. A single screw extruder was used to produce the starch - monoglyceride complex before film production and this process was effective to inhibit the phase separation in films. The addition of the hydrophobic compound reduced hydrophobicity, transparency and water vapor permeability of films. This later value for starch-glycerol film $\left(1.7 \times 10^{-10} \mathrm{~g} \mathrm{~Pa}^{-1} \mathrm{~s}^{-1} \mathrm{~m}^{-}\right.$ $\left.{ }^{1}\right)$ was higher than starch $\left(1.2 \times 10^{-10} \mathrm{~g} \mathrm{~Pa}^{-1} \mathrm{~s}^{-1} \mathrm{~m}^{-1}\right)$ and monoglyceride-starch films $\left(1.0 \times 10^{-10} \mathrm{~g} \mathrm{~Pa}^{-1} \mathrm{~s}^{-1} \mathrm{~m}^{-1}\right)$. Films containing glycerol had higher relative crystallinity $\left(B\right.$ and $\left.V_{H}\right)$ with a slight increase at higher $R H$ values, while for monoglyceride films, the crystallinity was constant. Monoglyceride-starch films presented poor mechanical properties when compared to glycerol-starch ones but they presented a stable behavior under different relative humidities.
\end{abstract}

Key words: biodegradable films, hydrophilicity and glycerol-monoestearate

\section{INTRODUCTION}

Biopolymer films and coatings from polysaccharides, proteins and lipids formulated either with one or more components have potential to control mass transfer and, thus, extend food shelf life, as compared to traditional packaging (Parris et al., 1995; García et al., 1999, 2000). Being totally degradable, biopolymers could contribute to reducing the amount of plastic wastes. In addition, these polymers are obtained from renewable sources, unlike the synthetic polymers (Souza and Andrade, 2000).

The first studies about the use of starch in biodegradable food packaging were based on substituting part of the synthetic matrix by starch (below 10\%). However, the main difficulties found were attributed to chemical incompatibility of starch with synthetic polymers (Griffin, 1977). Recently, many works dealt with the addition of plasticizers to pure starch-based materials to overcome the film brittleness caused by high

*Author for correspondence: victoria@ uel.br 
intermolecular forces (Bader and Göritz, 1994; Lourdin et al., 1995; Souza and Andrade, 2000; García et al., 2000; Larotonda et al., 2004; Mali et al., 2002; 2004).

The usefulness of starch films is somewhat limited because their mechanical and barrier properties are dependent on moisture (Krochta and MulderJohnston, 1997). They become brittle in a dry atmosphere and lose strength and barrier properties in high humidity. The moisture sensitivity in particular must be reduced if starch is to become an alternative to conventional plastics in industrial applications (Petersson and Stading, 2005).

Although some good solutions have been found until now as blends of starch with natural or synthetics biodegradable polyesters (polylactic acid, polycaprolactone, etc.), multilayer films or addition of nanocomposites, these cannot be used still for wide applications because of their relatively high price (Wilhelm et al., 2003; Campos and Franchetti, 2005; Ray and Bousmina, 2005).

At same time, much work has been done to examine the water vapor barrier properties of films made from other biopolymers, like wheat gluten, zein and methylcellulose with added lipids or waxes (Gontard et al., 1994; Weller et al., 1998) and although a great deal of research has been done on edible films made of renewable and biodegradable substances with respect to their barrier and mechanical properties, there has been little research on starch-lipid films.

Garcia et al. (2000) analyzed the barrier properties of starch-based films and coatings from corn and high amylose corn with addition of sunflower oil as hydrophobic component and with a plasticizer present. Petersson and Stading (2005) studied the mechanical and barrier properties of starchmonoglyceride films and observed a decrease in water vapor permeability. Nevertheless, they reported that phases separation occurred in films with high amount of monoglyceride (about 10 $\mathrm{g} / 100 \mathrm{~g}$ starch).

According to Eliasson and Kim (1995), amylose presented the ability to form complexes with monoglycerides, which depended on their physical state and thus, the utilization of extrusion cooking in the mixture of starch and monoglycerides could be an alternative to overcome the phase separation. Yam starch, due to its high concentration of amylose (higher than 30\%) has been related as raw material with potential good results in the production of biodegradable films, such as stability during storage and others (Mali et al., 2002; 2004; Wilhelm et al., 2003).

The objectives of this work were to produce the casted films with yam starch, complexed with monoglyceride (glycerol-monoestearate) and to evaluate its microstructural, barrier and mechanical properties in different relative humidities.

\section{MATERIALS AND METHODS}

\section{Materials}

Fresh tubers of yam (Dioscorea alata), with uniform size and shape, without any mechanical and pathological injuries, were obtained from a local farm (Londrina - PR, Brazil). Yam starch was extracted according to Alves et al. (1999), which presented the following composition on dry basis: ash $=0.21 \pm 0.01 \%$, protein $=0.50 \pm 0.01 \%$ and lipids $=0.07 \pm 0.02 \%$ and amylose $=33.7 \%$.

The monoglyceride employed was the glycerolmonoestearate that was supplied by Ceralit S/A (Campinas - Brazil), and had a melting point of $55-62^{\circ} \mathrm{C}$.

\section{Complex starch - monoglyceride preparation}

Yam starch and the monoglyceride were mixed for $15 \mathrm{~min}$ in an electric mixer using a monoglyceride concentration of $2 \mathrm{~g} / 100 \mathrm{~g}$ starch, with a moisture content adjusted at $18 \%$ with distilled water. A single screw extruder (Cerealtec CT-L15, Campinas, Brazil) was used to produce the complex starch - monoglyceride. The extruder was coupled with a barrel of $420 \mathrm{~mm}$ in length and $19.4 \mathrm{~mm}$ in diameter, 1:2 compression ratio screw and $5 \mathrm{~mm}$ die diameter. The extrusion temperature was maintained at $70-80^{\circ} \mathrm{C}$ for the feeding section, and $145^{\circ} \mathrm{C}$ for the mixing and metering sections. Screw speed was fixed in $120 \mathrm{rpm}$. The extruded samples were collected and dried at $55^{\circ} \mathrm{C}$ in a forced-air convection oven (Tecnal TE 394-3 Brazil) during $12 \mathrm{~h}$ and were finely ground in a Quimis Mill (Q-298 A21- Brazil).

\section{Differential scanning calorimetry}

Native and complexed yam starches were tested in a Shimadzu DSC, model 50 (Shimadzu Corporation, Japan) to confirm the formation of the complex starch-monoglyceride. Samples of 1 $\mathrm{mg}$, mixed with $3 \mu \mathrm{L}$ of distilled water, were stored for $12 \mathrm{~h}$ in aluminum pans hermetically 
sealed; an empty pan was used as reference. Samples were heated from 20 to $160^{\circ} \mathrm{C}$ with $10^{\circ} \mathrm{C} / \mathrm{min}$ heating rate. All measurements were performed in duplicate.

\section{Films preparation}

The films were prepared by mixing the starchmonoglyceride complex (4 g/100 g solution) with distilled water to make batches with a total weight of $500 \mathrm{~g}$. The film-forming solutions were transferred quantitatively to the viscograph cup of a Brabender Viscograph Pt 100 (OHG, Duisburg, Germany). They were heated from 30 to $95^{\circ} \mathrm{C}$ and maintained at $95{ }^{\circ} \mathrm{C}$ for $10 \mathrm{~min}$, with regular shaking $(75 \mathrm{rpm})$ and constant $\left(3^{\circ} \mathrm{C} / \mathrm{min}\right)$ heating rate (this treatment did not disrupt the starchmonoglyceride complex as proved by DSC tests data not shown). The films were prepared by casting and gelatinized suspensions were immediately poured on rectangular acrylic plates $(10 \times 20 \mathrm{~cm})$. The quantity of starch suspension poured onto the acrylic plates was calculated to obtain the films with $0.11 \pm 0.01 \mathrm{~mm}$ of thickness, measured with a Mitutoyo micrometer (São Paulo - Brazil). The starch suspensions were dried at 45 ${ }^{\circ} \mathrm{C}$ in a ventilated oven model TE-394-3 (Tecnal, Piracicaba, SP, Brazil) to constant weight (about $20 \mathrm{~h}$ ). Starch films without monoglyceride (4 g starch/100 g filmogenic solution) and glycerolstarch films (4 g yam starch and $1.3 \mathrm{~g}$ glycerol $/ 100$ $\mathrm{g}$ filmogenic solution) were produced at the same conditions; which were included in the study for comparative purpose. Glycerol and starch concentrations were established in a previous study (Mali et al., 2002).

All the films were stored for seven days before the analysis. They were placed at $25 \pm 2^{\circ} \mathrm{C}$ in separated desiccators over saturated salt solutions ( $\left.\mathrm{LiCl}, \mathrm{MgCl}_{2}, \mathrm{Mg}\left(\mathrm{NO}_{3}\right)_{2}, \mathrm{NaCl},\left(\mathrm{NH}_{4}\right)_{2} \mathrm{SO}_{4}\right)$ that respectively establish the desired relative humidity $(11,33,54,75$ and $81 \% \mathrm{RH})$ conditions.

\section{Films characterization}

\section{Adsorption isotherms}

Film specimens $(30 \mathrm{~mm} \times 30 \mathrm{~mm})$ were pre-dried for 7-days over phosphorous pentoxide $\left(\mathrm{P}_{2} \mathrm{O}_{7}\right)$ and then were placed in desiccator at $25 \pm 2{ }^{\circ} \mathrm{C}$, over saturated salt solutions having different relative humidity $(11,33,54,75$ and $81 \% \mathrm{RH})$ conditions. Each film specimen was weighed at regular intervals, and when two consecutive weighings were equal, it was assumed that an equilibrium condition was reached. Under the above conditions, an equilibrium period of 3-days was sufficient to establish the moisture equilibrium. Equilibrium moisture content was calculated from the increase in mass of the dried sample after equilibration at a given RH.

GAB (Guggenheim - Anderson - de Boer) model was used to fit yam starch film sorption isotherm data and monolayer values were calculated from the equations (Bizot, 1984). GAB isotherm model can be expressed as follows: $\mathrm{M}=\mathrm{m}_{0} \mathrm{CKa}_{\mathrm{w}} /(1-$ $\left.\mathrm{Ka}_{\mathrm{w}}\right)\left(1-\mathrm{Ka}_{\mathrm{w}}+\mathrm{CKa}_{\mathrm{w}}\right)$, where $\mathrm{M}$ is the equilibrium moisture content at a water activity $\left(\mathrm{a}_{\mathrm{w}}\right), \mathrm{m}_{0}$ is the monolayer value (g water/ $100 \mathrm{~g}$ solids) and $\mathrm{C}$ and $\mathrm{K}$ are the $\mathrm{GAB}$ constants.

\section{Water vapor permeability (WVP)}

WVP tests were conducted using ASTM (1995) method E96. Each film sample was sealed over a circular opening of $0.00181 \mathrm{~m}^{2}$ in a permeation cell that was stored at $25^{\circ} \mathrm{C}$ in a desiccator. To maintain a $100 \% \mathrm{RH}$ gradient across the film, anhydrous calcium chloride $(0 \% \mathrm{RH})$ was placed inside the cell and distilled water $(100 \% \mathrm{RH})$ was used in the desiccator. The RH inside the cell was always lower than the outside, and water vapor transport was determined from the weight gain of the permeation cell. After steady state conditions were reached (about $2 \mathrm{~h}$ ), eight weight measurements were made over $24 \mathrm{~h}$. Changes in the weight of the cell were recorded to the nearest $0.0001 \mathrm{~g}$ and plotted as a function of time. The slope of each line was calculated by linear regression $\left(\mathrm{r}^{2}>0.99\right)$ and the water vapor transmission rate (WVTR) was calculated from the slope of the straight line $(\mathrm{g} / \mathrm{s})$ divided by the cell area $\left(\mathrm{m}^{2}\right)$. After the permeation tests, film thickness was measured and WVP $\left(\mathrm{g} \mathrm{Pa}^{-1} \mathrm{~s}^{-1} \mathrm{~m}^{-1}\right)$ was calculated as WVP $=\left[\mathrm{WVTR}=\mathrm{S}\left(\mathrm{R}_{1}-\mathrm{R}_{2}\right)\right] \mathrm{d}$; where $S$ is the saturation vapor pressure of water (Pa) at the test temperature $\left(25^{\circ} \mathrm{C}\right), \mathrm{R}_{1}$, the $\mathrm{RH}$ in the desiccator, $\mathrm{R}_{2}$, the $\mathrm{RH}$ in the permeation cell and $\mathrm{d}$ is the film thickness (m).

\section{$X$-ray diffraction}

Samples were analyzed between $2 \theta=2^{\circ}$ and $2 \theta=$ $60^{\circ}$ with a step size $2 \theta=0.02^{\circ}$ in a X-ray diffractometer Philips PW 1710 (The Netherlands) using a $\mathrm{Cu}$ Ka radiation $(\lambda=1.543)$, and $40 \mathrm{kV}$ and $30 \mathrm{~mA}$. Relative crystallinity was calculated for B and $\mathrm{V}_{\mathrm{H}}$ crystals by dividing the area of the diffraction peaks at $2 \theta=17^{\circ}$ and $22^{\circ}$ (for B-type) 
and $2 \theta=19.8^{\circ}$ (for $\mathrm{V}_{\mathrm{H}^{-}}$-type) by the total area of the diffractogram (Hullemann et al., 1999).

\section{Mechanical properties}

The tensile properties of starch films were determined using a TA.TX2i Stable Micro Systems texture analyzer (Surrey - England) in accordance with ASTM D-882-91 method (1996). The samples were clamped between the pneumatic grips and force $(\mathrm{N})$ and deformation $(\mathrm{mm})$ were recorded during extension at $50 \mathrm{~mm} \cdot \mathrm{min}^{-1}$ and with an initial distance between the grips of 50 $\mathrm{mm}$. The parameters determined were: stress at break (MPa) and strain at break (\%). Five film specimens $(100 \mathrm{~mm} \times 25 \mathrm{~mm})$ of each formulation were used in the analysis

\section{RESULTS AND DISCUSSION}

The films obtained were translucent and easily removed from the plate.
The DSC thermogram of native yam starch (Fig. 1a) presented an endothermic peak at $63.3^{\circ} \mathrm{C}$ that could be attributed to the starch gelatinization. The monoglyceride-complexed starch (Fig. 1b) did not present an endothermic peak at this temperature, probably because the extrusion process was effective in gelatinization of starch granules. In addition, another endothermic peak was observed at $95.7^{\circ} \mathrm{C}$ and this could be attributed to the melting of the starch-monoglyceride complex (Fig. 1b). These data was according to Tufvesson and Eliasson (2000) who reported an endothermic peak between 96 and $120^{\circ} \mathrm{C}$ in potato starches complexed with monoglycerides and related it to the melting of this complex.

The presence of glycerol or monoglyceride affected the final appearance of the films and only a slight phase separation was observed on monoglyceride starch films, which were more opaque than starch and glycerol-starch films probably because the hydrophobicity conferred by the monoglyceride.

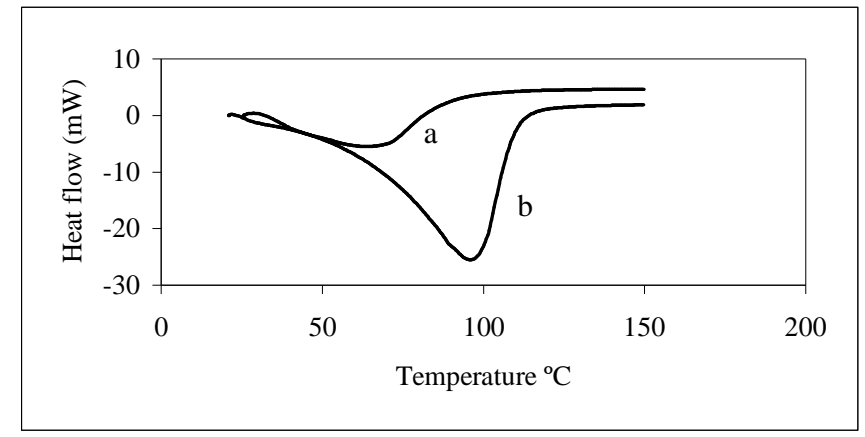

Figure 1 - DSC thermograms of (a) native yam starch (peak temperature $=63.3^{\circ} \mathrm{C}$ ) and (b) monoglyceride-starch complex (peak temperature $=95.7^{\circ} \mathrm{C}$ ).

According to Petersson and Stading (2005), monoglyceride concentration affected the final appearance of casted starch films, which became more opaque and shrunken at higher monoglyceride concentrations (about $10 \mathrm{~g} / 100 \mathrm{~g}$ starch). In this study, two factors probably inhibited the phase separation in monoglyceride starch films: the extrusion process employed to form the starch-monoglyceride complex and the lower monoglyceride concentration employed in film formulations ( $2 \mathrm{~g} / 100 \mathrm{~g}$ starch).

\section{Adsorption isotherms}

The sorption isotherms of starch and glycerol- starch films (control samples) were compared with those of monoglyceride starch films (Fig. 2). The isotherms showed a similar sigmoid shape (isotherm type II) and glycerol films showed higher equilibrium moisture content in all water activities. This could be explained by the difference between the films formulations; while glycerol was a hydrophilic plasticizer, the addition of a hydrophobic compound as a monoglyceride probably reduced the water binding capacity of the films.

To improve the investigation about water sorption behavior, the adsorption data obtained were fitted using GAB model (Bizot, 1984). As shown in 
Figure 2, the GAB model adjusted well to experimental points $\left(\mathrm{r}^{2}=0.99\right)$; films with glycerol showed highest monolayer value $(0.087 \mathrm{~g}$ water/ $\mathrm{g}$ solids) and monoglyceride-starch films $(0.081 \mathrm{~g}$ water/ g solids) the lower. The monolayer value indicated the maximum amount of water that could be adsorbed in a single layer per gram of dry film and was a measure of number of sorbing sites (Strauss et al., 1991). The addition of an hydrophilic plasticizer provides more active sites by exposing its hydroxyl groups in which the water molecules could be adsorbed (Mali et al., 2005).

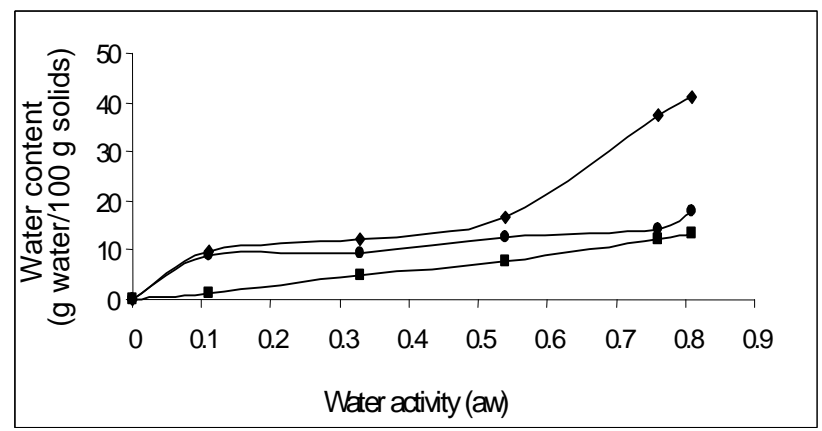

Figure 2 - Sorption isotherms at $25^{\circ} \mathrm{C}$ for: $\bullet=$ starch films, $\boldsymbol{\bullet}=$ starch-glycerol films and $\mathbf{\square}=$ starch-monoglyceride films. The lines were derived from GAB model.

\section{Water vapor permeability (WVP)}

The WVP of glycerol starch films $\left(1.7 \times 10^{-10} \mathrm{~g} \mathrm{~Pa}^{-}\right.$ ${ }^{1} \mathrm{~s}^{-1} \mathrm{~m}^{-1}$ ) was significantly higher (Tukey test, $\mathrm{p} \leq$ 0.05) than starch $\left(1.2 \times 10^{-10} \mathrm{~g} \mathrm{~Pa}^{-1} \mathrm{~s}^{-1} \mathrm{~m}^{-1}\right)$ and monoglyceride starch films $\left(1.0 \times 10^{-10} \mathrm{~g} \mathrm{~Pa}^{-1} \mathrm{~s}^{-1}\right.$ $\mathrm{m}^{-1}$ ). These results were an indicative that monoglyceride addition to starch structure can be effective in reducing moisture transfer. According to Petersson and Stading (2005), the effectiveness of monoglycerides to improve barrier properties in starch films was affected by the phase separation. In the films with phase separation, the WVP increase instead decrease because the films structures have areas without the hydrophobic compound.

\section{X-ray diffraction}

The crystallinity pattern of films (similar to that showed in Fig. 3) could be assigned to a B-type (high intensity peaks at $2 \theta=17$ and 22.1), characteristic of biofilms containing starch (van Soest and Vliegenthart, 1997; Mali et al., 2002). $\mathrm{V}_{\mathrm{H}}$ crystals (high intensity peaks at $2 \theta=19.8$ ) were also observed. The X-ray diffractograms were used for the purpose of calculating the relative crystallinity of starch films at specific angles that corresponded at particular crystal types.

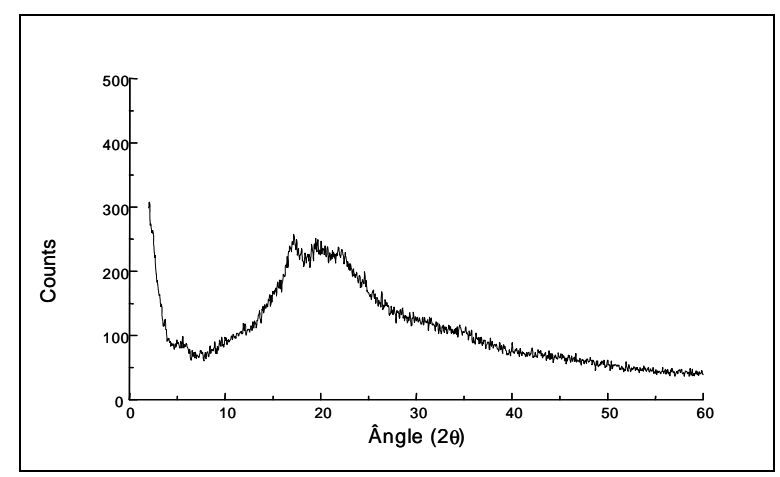

Figure 3 - X-ray diffractogram profile observed in the different films. 
In Figure 4 , the relative crystallinities for $\mathrm{B}$ and $\mathrm{V}_{\mathrm{H}}$ crystals were plotted against the different relative humidities tested for films storage. In both cases glycerol films presented higher crystallinity degree, with a slight increase at higher RH values, while monoglyceride starch films showed constant crystallinity degree (Fig. 3). Rindlav-Westling et al. (1998) demonstrated that increasing levels of relative humidities increased the relative crystallinity of glycerol plasticized amylopectin films. Theorically, the $\mathrm{V}_{\mathrm{H}}$ structure is found in extruded starches (van Soest et al., 1996) and in this work should be appeared more significantly in the monoglyceride starch films, but probably the short storage time and the low water content did not favored the starch crystallization in these films.

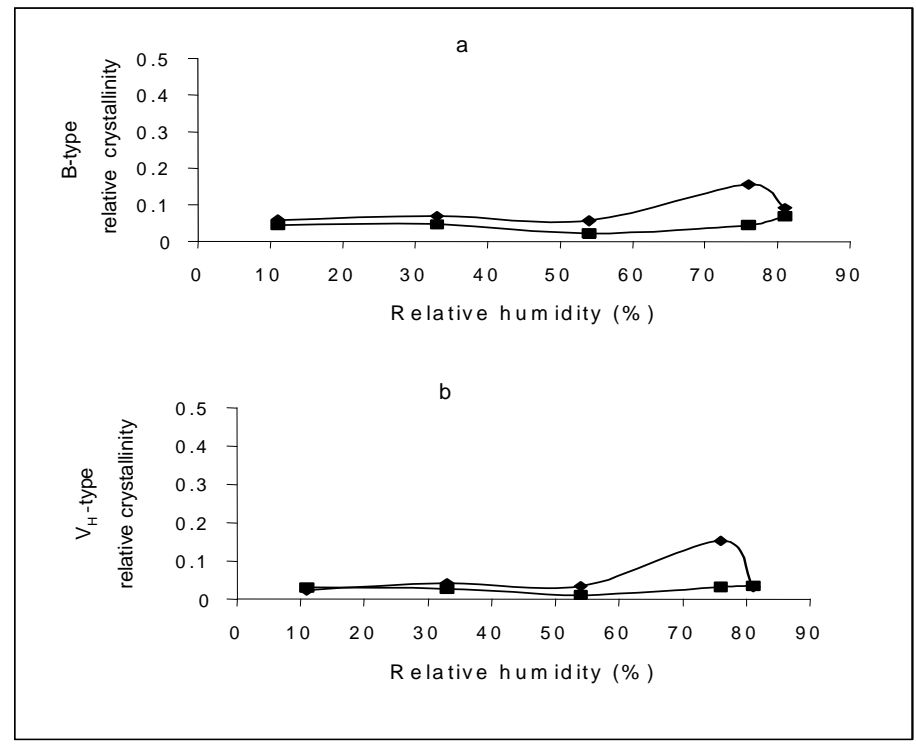

Figure 4 - Type-B (a) and Type $\mathrm{V}_{\mathrm{H}}$ (b) relative crystallinity of $\boldsymbol{\nabla}=$ starch- glycerol films and $\mathbf{\square}=$ starch-monoglyceride films.

\section{Mechanical properties}

Starch films and glycerol plasticized films showed large variations in stress and strain at break under different RH; a decrease in stress and an increase in strain were evidenced when RH increased (Fig. 5 ). The decrease of stress and the increase of strain in starch films were related with the variation of water content in these hydrophilic materials and has been reported previously (Cuq et al., 1995; Parris et al., 1995; Monterrey and Sobral, 1999, Mali et al., 2004; 2005). Structural modifications occurred in starch network when these plasticizers were incorporated. Water and glycerol molecules are small and present high capacity to interact with starch chains, enhancing the molecular mobility and increasing free volume in the film matrix, leading more weak and flexible films (Mali et al.,
2004; 2005). Although monoglyceride starch films presented poor mechanical properties when compared to starch and glycerol-starch films, they presented a desirable stable behavior under different relative humidity (Fig. 5).

The low stress at break could be related to the weakening effect of the monoglyceride on the starch network (Petersson and Stading, 2005), probably the monoglyceride groups sterically interfered with the intermolecular alignment of starch chains, decreasing its tendency to form hydrogen bonds (Wurzburg, 1986).

The lower flexibility presented by these films agreed with isotherms data, which showed that monoglyceride starch films had a lower water binding capacity, and this probably conferred lower flexibility to them. 

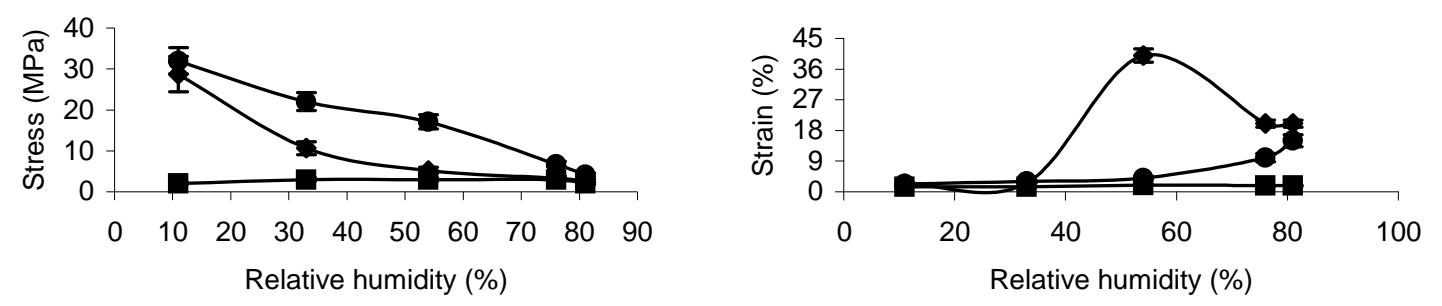

Figure 5 - Stress at break and strain at break for:

- = starch-monoglyceride films.

\section{CONCLUSIONS}

The use of extrusion cooking to complex yam starch and monoglyceride was effective and permitted to produce starch-monoglyceride films with only a slight phase separation. The high stability of mechanical properties of starchmonoglyceride films submitted to different $\mathrm{RH}$ conditions was its most desirable characteristic, and at the same time, these films showed lower hydrophilicity and water vapor permeability than starch and glycerol-starch films. The tensile tests showed that the monoglyceride had a weakening effect on the films, suggesting that it was the starch interactions that provided most of the tensile strength. Although starch-monoglyceride films presented poor mechanical properties when compared with glycerol films, they could have application as packing for fast food, for example, that do not require high resistance or elongation.

\section{ACKNOWLEDGMENTS}

The authors wish to thanks the financial support provided by CYTED, CAPES, CAPES-ProDoc program and CNPq.

\section{RESUMO}

Estudou-se o efeito da adição de monoglicerídeo nas propriedades microestruturais, mecânicas e de barreira de filmes de amido de inhame, em diferentes umidades relativas (UR), comparando-as com as de filmes de amido- glicerol. Uma extrusora mono-rosca foi usado para produzir o complexo amido-monoglicerídeo, antes de produzir o filme, e o processo foi efetivo para inibir a separação de fases que geralmente ocorre nesse tipo de filmes. A adição de monoglicerídeo, que é um composto hidrofóbico, reduziu a hidrofilicidade, a transparência e a permeabilidade ao vapor de água dos filmes. $\mathrm{O}$ valor desta, para os filmes de amido-glicerol $\left(1,7 \times 10^{-10} \mathrm{~g} \mathrm{~Pa}^{-1} \mathrm{~s}^{-1} \mathrm{~m}^{-1}\right)$ foi maior que para os de amido $\left(1,2 \times 10^{-10} \mathrm{~g} \mathrm{~Pa}^{-1} \mathrm{~s}^{-}\right.$ $\left.{ }^{1} \mathrm{~m}^{-1}\right)$ e para os de amido-monoglicerídeo $(1,0 \mathrm{x}$ $\left.10^{-10} \mathrm{~g} \mathrm{~Pa}^{-1} \mathrm{~s}^{-1} \mathrm{~m}^{-1}\right)$. Os filmes com glicerol tiveram maior cristalinidade relativa $\left(B\right.$ e $\left.V_{H}\right)$, com um ligeiro aumento em altas UR, enquanto que nos filmes com monoglicerídeo a cristalinidade foi constante. Os filmes de amido-monoglicerídeo apresentaram piores propriedades mecânicas que os filmes de amido-glicerol, mas foram mais estáveis sob diferentes umidades relativas.

\section{REFERENCES}

Alves, R. M. L.; Grossmann, M. V. E.; Silva, R. S. S. F. (1999), Pregelatinized starches of Dioscorea alata: Functional properties. Food Chemistry, 67, 23-127.

ASTM (1996). Standard Test Methods for Tensile Properties of Thin Plastic Sheeting, D882-91. Annual book of ASTM. Philadelphia, PA: American Society for Testing and Materials.

ASTM (1996). Standard test methods for water vapor transmission of material, E96-95. Annual book of ASTM. Philadelphia, PA: American Society for Testing and Materials.

Bader, H. G.; Göritz, D. (1994), Investigations on high amylose corn starch films. Part 2: water vapor sorption. Starch/Stärke, 46, 249-252.

Bizot, H. (1984), Using the GAB model to construct sorption isotherms. In - Physical properties of foods. Eds R. Jowitt; F. Escher; B. Hallistrom; H.F.T. Meffert; W.E.L. Spiess; G. Vos. Applied Science Publishers, London, pp. 27-41.

Campos, A.; Franchetti, S. M. M. (2005), Biotreatment effects in films and blends of PVC/PCL previously treated with heat. Brazilian Archives of Biology and Technology, 48, 235-243. 
Cuq, B.; Aymard, C.; Cuq, J. L.; Guilbert, S. (1995), Edible packaging films based on fish myofibrillar proteins: formulation and functional properties. Journal of Food Science, 60, 1369-1374.

Eliasson, A. C.; Kim, G. R. A. (1995), A dynamic rheological method to study the interaction between starch and lipids. Journal of Rheology, 39, 1519-1525.

Freitas, R. A.; Paula, R. C.; Feitosa, J. P. A.; Rocha, S.; Sierakowski, R. M. (2004), Amylose contents, rheological properties and gelatinization kinetics of yam (Dioscorea alata) and cassava (Manihot utilissima) starches. Carbohydrate Polymers, 55, 3-8.

García, M. A.; Martino, M. N.; Zaritzky, N. E. (1999), Edible starch films and coatings characterization: scanning electron microscopy, water vapor transmission and gas permeabilities. Scanning, 21, 348-353.

Garcia, M. A.; Martino, M. N.; Zaritzky, N. E. (2000), Lipid addition to improve barrier properties of edible starch-based films and coatings. Journal of Food Science, 65, 941-947.

Gontard, N.; Duchez, C.; Cuq, J. L.; Guilbert, S. (1994), Edible composite films of wheat gluten and lipids: Water vapour permeability and other physical properties. International Journal of Food Science and Technology, 29, 39-50.

Griffin, G. J. L. (1977), US PATENT n ${ }^{\circ} 4.021 .388$.

Hullemann, S. H. D.; Kalisvaart, M. G.; Janssen, F. H. P.; Feil, H.; Vliegenthart, J. F. G. (1999), Origins of B-type crystallinity in glycerol-plasticized, compression moulded potato starches. Carbohydrate Polymers, 39, 351-360.

Krochta, J. M.; Mulder-Johnston, C. (1997), Edible and biodegradable polymer films: Challenges and opportunities. Food Technology, 51, 61-74.

Larotonda, F. D. S.; Matsui, K. N.; Soldi, V.; Laurindo, J.B. (2004), Biodegradable films made from raw and acetylated cassava starch. Brazilian Archives of Biology and Technology, 47, 477-484.

Lourdin, D.; Della Valle, G.; Colonna, P. (1995), Influence of amylose content on starch films and foams. Carbohydrate Polymers, 27, 275-280.

Mali, S.; Grossmann, M. V. E.; García, M. A.; Martino, M. M.; Zaritzky, N. E. (2002), Microstructural characterization of yam starch films. Carbohydrate Polymers, 50, 379-386.

Mali, S.; Grossmann, M.V.E.; García, M.A.; Martino, M.M.; Zaritzky, N.E. (2004), Barrier, mechanical and optical properties of plasticized yam starch films. Carbohydrate Polymers, 56, 129-135.

Mali, S.; Sakanaka, L.; Yamashita, F.; Grossmann, M.V.E. (2005), Water sorption and mechanical properties of cassava starch films and their relation to plasticizing effect. Carbohydrate Polymers, 60, 283289.

Monterrey, E. S.; Sobral, P. J. A. (1999), Caracterização de propriedades mecânicas e óticas de filmes a base de proteínas miofibrilares de tilápia do Nilo usando uma metodologia de superfície de resposta. Ciência e Tecnologia de Alimentos, 19, 294-301.

Parris, N.; Coffin, D. R.; Joubran, R. F.; Pessen, H. (1995), Composition factors affecting the water vapor permeability and tensile properties of hydrophilic films. Journal of Agriculture and Food Chemistry, 43, 1432-1435.

Petersson, M.; Stading, M. (2005), Water vapor permeability and mechanical properties of mixed starch-monoglyceride films and effect of film forming conditions. Food Hydrocolloids, 19, 123-132.

Ray, S. S.; Bousmina, M. (2005), Biodegradable polymers and they layered silicate nanocompósitos: In greening the 21 st century materials world. Progress in Material Science, 50, 962-1079.

Rindlav-Westling, A.; Stading, M.; Hermansson, A. M.; Gatenholm, P. (1998), Structure, mechanical and barrier properties of amylose and amylopectin films. Carbohydrate Polymers, 36, 217-224.

Rockland, L. B. (1960), Satured salt solutions for static control of relative humidity. Analytical Chemistry, 32, 1375-1376.

Souza, R. C. R.; Andrade, C. T. (2000), Investigação dos processos de gelatinização e extrusão de amido de milho. Polímeros: Ciência e Tecnologia, 10, 24-30.

Strauss, U. P.; Porcja, R. J.; Chen, Y. (1991), Volume effects of starch water interactions. In - Water relationships in foods, ed. H. Levine; L. Slade. Plenum Press, New York, pp. 351-364.

Tufvesson, K. N.; Eliasson, A. C. (2000), Formation and crystallization of amylose-monoglyceride complex in starch matrix. Carbohydrate polymers, $\mathbf{4 3 ,}$ 359-365.

van Soest, J. J. G.; Hulleman, S. H. D.; de Wit, D.; Vliegenthart, J. F. G. (1996), Crystallinity in starch bioplastics. Industrial Crops and Products, 5, 11-22.

van Soest, J.J.G; Vliegenthart, J.F.G. (1997), Crystallinity in starch plastics: consequences for material properties. Trends in Biotechnology, 15, 208213.

Weller, C. L.; Gennadios, A.; Saraiva, R. A. (1998), Edible bilayer films from zein and grain sorghum wax or carnauba wax. Lebensmittel-Wissenschaft undTechnologie, 31, 279-285.

Wilhelm, H.; Sierakowski, M. R.; Souza, G. P.; Wypych, F. (2003), Starch films reinforced with mineral clay. Carbohydrate Polymers, 52, 101-110.

Wurzburg, O. B. (1986), Cross-linking starches. In Modified Starches: Properties and uses. ed. O. Wurzburg. CRC Press, Boca Raton, pp. 41-53.

Received: December 22, 2006; Revised: August 20, 2007 Accepted: February 13, 2009. 